\title{
THE UTILIZATION OF UNWRITTEN LAWS IN BANKRUPTCY DISPUTES
}

\author{
(Penggunaan Hukum Tidak Tertulis Dalam Sengketa Kepailitan)
}

\author{
M. Hadi Shubhan \\ Fakultas Hukum Universitas Airlangga \\ Jl. Dharmawangsa Dalam Selatan Surabaya \\ Email : hadi@fh.unair.ac.id
}

Naskah diterima: 23 Januari 2019; revisi: 15 Februari 2019; disetujui: 19 Maret 2019

\begin{abstract}
Unwritten laws hold a strategic role in bankruptcy dispute settlement, both in the act of bankruptcy and in the management and settlement of a bankruptcy estate after the debtor is declared bankrupt. This paper will discuss about the characteristics of Indonesia bankruptcy law and the legal basis and theoretical basis for the possibility of using unwritten law in bankruptcy cases. This research employed a doctrinal legal research method with a statute approach, a conceptual approach, and a case approach. In Article 8 paragraph (6) of Law No. 37 of 2004 made it possible for judges to use an unwritten law as the basis in deciding on act of bankruptcy. Similarly, in regard to the management and settlement of a bankruptcy estate, some norms provide some space for the supervisory judge's and curators to make a decision or take action based on the principles of unwritten justice. In a number of court decisions, the law has also not been written down in consideration of its law.
\end{abstract}

Keywords: unwritten law, bankruptcy, dispute

\section{Abstrak}

Hukum tidak tertulis memiliki peran yang strategis dalam penyelesaian sengketa kepailitan, baik dalam permohonan kepailitan maupun dalam pengurusan dan pemberesan harta pailit setelah debitor dinyatakan pailit. Tulisan ini hendak membahas mengenai karakteristik kepailitan di Indonesia dan dasar hukum dan dasar teoritis kemungkinan digunakannya hukum tidak tertulis dalam perkara kepailitan. Metode penelitian yang digunakan adalah metode penelitian hukum doktrinal, dengan menggunakan pendekatan perundang-undangan, pendekatan konseptual, dan pendekatan kasus. Dari penelitian ini ditemukan bahwa dalam Pasal 8 ayat (6) UU No. 37 Tahun 2004 dimungkinkan hakim menggunakan dasar hukum tidak tertulis dalam memutus permohonan kepailitan. Demikian pula dalam proses pengurusan dan pemberesan harta pailit, terdapat beberapa norma yang memungkinkan ruang diskresi bagi hakim pengawas dan kurator untuk mengambil putusan atau tindakan berdasarkan prinsip-prinsip keadilan yang tidak tertulis. Dalam beberapa putusan pengadilan juga sudah menggunakan hukum tidak terpulis dalam pertimbanagn hukumnya.

Kata kunci: hukum tidak tertulis, kepailitan, sengketa 


\section{A. Introduction}

In general, the norms of procedural law aim to prioritize procedural justice principles by slightly overriding the substantial aspects of justice itself. Procedural law often emphasizes textual written rules, and disregards contextual and unwritten laws. These characteristics are not fully adhered to within bankruptcy law. Law Number 37 of 2004 on Bankruptcy and the Suspension of Debt Payment Obligation (hereinafter referred to as The Bankruptcy Law) primarily regulates procedural law regarding acts of bankruptcy and the management and settlement of a bankruptcy estate. Although limited, Bankruptcy Law provides space for unwritten laws in bankruptcy-related aspects, both in the act of bankruptcy for debtors and in various disputes and actions related to the management and settlement of a bankruptcy estate.

Enabling adherence to unwritten laws in Bankruptcy law is intended to provide some substantial justice space for justice seekers (justiabelen). Substantial justice is strategic in bankruptcy law, as the bankrupt verdict results in the "death" of civil rights in the management of the debtor's property. In addition to bankruptcy, for the sake of law, the debtor loses his/her ability and authority to make arrangements for all of his/her assets, including losing the authority to conduct any transactions concerning his/her property. Indeed, once the debtor is declared bankrupt by the judge, the debtor's assets become the bankrupt estate, which is managed by the curator under the supervision of the supervisory judge.

The role of unwritten laws in Bankruptcy Law is explicitly stated in Article 8 paragraph (6) letter a, which reads "The Court's verdict, as referred to in paragraph (5), must also include: a. A certain article of the relevant statutory regulations and/or an unwritten legal source which becomes the basis for the trial". This article becomes legitimizes a judge's decision based on unwritten laws. For judges, unwritten laws seek to uphold unwritten norms, such as justice (beyond the written articles), propriety, fairness, etc.

The utilization of unwritten law by judges in adjudicating bankruptcy, among others, is related to fulfilling the requirements of an act of bankruptcy. For an act of bankruptcy to have occurred, two conditions must be fulfilled, namely: (1) the existence of debt that is not paid in full or that has fallen due so it can be billed, and (2) the existence of at least two creditors as material conditions. The Bankruptcy Law must fulfil an evidence requirement, namely summarily proving. The problem arises due to the fact that is unclear whether the judge is bound solely by the two terms and the summarily proving, or whether the judge can consider other aspects in deciding on The Bankruptcy Law. If so, a judge is merely a puppet of the law, and Article 8 paragraph (6) of Bankruptcy Law (which allows judges to consider unwritten laws in their decisions) is ineffectual. Thus, it is necessary to thoroughly study the application of unwritten laws in bankruptcy pronouncements.

In addition to being utilized as the basis for judges' decisions regarding an act of bankruptcy, unwritten laws also play a strategic role in the management and settlement of a bankruptcy estate when a debtor is declared bankrupt. Some actions of the supervisory judges and curators are supported by Bankruptcy Law, and the choice is not implicitly set forth in the Bankruptcy Law. Therefore, the actions are under the discretionary authority, based on unwritten norms. If the actions taken by the 
supervisory judges or curators, and based on the discretionary authority, raise a dispute, this dispute can be brought before the administrative judge. In adjudicating disputes regarding the supervising judge's and/or curator's actions (based on the discretionary authority), the administrative judge will use unwritten laws as a test instrument (toetsing), such as the principles of justice, propriety, trustworthiness, reasonableness, etc.

The supervisory judges and curators can utilize unwritten laws when determining what actions to take when performing discretionary actions. Meanwhile, administrative judges can employ unwritten laws to examine the actions taken by the supervisory judges and curators based on discretional authority. This is because the test instruments (i.e. unwritten laws) cannot be used, since they are not regulated. From this phenomenon, it is necessary to examine what aspects are considered by supervising judges or curators when executing discretionary actions, and by the administrative judge when utilizing unwritten laws as a test instrument, so that it fulfils the element of legal certainty without ignoring the element of legal justice.

Unwritten laws can be utilized by bankruptcy case judges either to judge an act of bankruptcy or to adjudicate disputes due to a disparity between the supervisory judge's actions and the curator's verdict. Disparities in verdicts are also interesting to study because, although one verdict may be different from another, the reasons for the different decisions (ratio decidendi) may have the horizon of benefits to develop legal studies (rechts-beoefening), especially in laws regarding bankruptcy cases.

Based on the aforementioned findings, this paper seeks to determine what are the characteristics of bankruptcy law in Indonesia, whether the use of unwritten law can be done either in bankruptcy applications or in the management and bankruptcy of assets.

\section{B. Research Method}

This research employed a normative legal research method with a statute approach, a conceptual approach, and a case approach. The legal objects studied were amassed from authoritative legal material, i.e. legislation and court decisions, as well as secondary legal objects such as relevant papers and scientific studies. This author intended to conduct theoretical-normative and praxis studies of the principles and norms/settings of bankruptcy law in Indonesia, as well as the practice of implementing bankruptcy law in court. As the primary factors in the determination of the legal basis of bankruptcy in Indonesia, various laws and regulations, as well as the decisions of the commercial court and the Supreme Court, are the research objects. Thus, both inductive and deductive reasoning were utilized in this study.

\section{Discussion}

\section{Bankruptcy Characteristics in Indonesia}

In the Indonesian legal system, three nomenclatures express a similar concept. Nevertheless, in this study, the three can be distinguished based on the normative context in regard to bankruptcy, insolvency, and financial distress. The insolvency/bankruptcy nomenclature is used for the status of a legal subject, whether that be a natural person (Natuurlijk persoon) or a law entity (rechtspersoon). Furthermore, the usage extends to a business entity that is not a legal entity, as established by the commercial court, and which 
loses his/her right to control and take care of his/her wealth as a consequence for not paying back a loan. Meanwhile, bankruptcy refers to the economic context of a situation concerning the uncertainty of a company's capability to continue its operations if its financial condition worsens. ${ }^{1}$ Meanwhile, financial distress refers to financial difficulties or liquidity, which may be the beginning of bankruptcy.

Within the context of Indonesian law, insolvency is related to the bankruptcy and financial distress of the debtor. Bankruptcy, however, may be unrelated to a bankruptcy case and the financial distress of debtors. This is because bankruptcy in Indonesia is only associated with the debtors' actions, when a loan is not paid in full. Many things may motivate the action of not paying a loan. Sometimes, a debtor cannot pay his/her debt due to shortterm financial distress or because the debtor's business is going bankrupt. However, it is also likely that the debtor is not experiencing any financial difficulties or undergoing bankruptcy. Instead, the debtor may be simply choosing not to make payments. A debtor's unwillingness to make payments can also be motivated by good or bad faith.

For example, if a debtor is unwilling to make payments due to good faith, perhaps the opposing party has not fulfilled a performance that should be completed first or the opposing party has not met the conditions that must be fulfilled. This was the case in the bankruptcy of PT. Telekomunikasi Seluler, which was decided in the Commercial Court of the Central Jakarta District Court (Case Number of 48/ PAILIT/2012/PN.NIAGA.JKT.PST in conjunction with the Cassation Decision Number 704 K/Pdt. Sus/2012), where PT. Telekomunikasi Seluler stopped sending cell phone top-up vouchers to its partner, PT. Prima Jaya, because PT. Prima Jaya was negligent in meeting performance expectations or previous requirements. Similarly, the case of the petition for the Suspension of Debt Payment Obligation (PKPU) of PT. Mahkota Sentosa as in the decision of the Commercial Court at the Central Jakarta District Court with Case Number 68/Pdt.Sus/PKPU/2018/ PN.Niaga.Jkt.Pst, where PT. Mahkota Sentosa did not wish to pay the bills submitted by PT. RTL and PT. ICK because the bill did not meet the required requirements such as the authority to sign advertising cooperation contracts, etc.

Conversely, a debtor's unwillingness to make payments may be due to its own bad faith, wherein he/she does not make payments due to pure default. This occurs frequently in bankruptcy cases in Indonesia, such as in the bankruptcy case of PT. Qurnia Subur Alam Raya, which was decided in the Commercial Court Decision of the Central Jakarta District Court (Case Number 09/Pdt.Sus/Pailit/2013/ PN.NIAGA.JKT.PST). This was also the case in the bankruptcy of PT. Central Java KSP Mandiri, which was decided by the Commercial Court of Semarang District Court (Case Number 13/Pdt. Sus-Pailit/2018/PN Niaga Smg in conjunction with 7/Pdt.Sus-PKPU/2016/PN Smg).

The politics of bankruptcy law in the Indonesian legal system function as a loan collection mechanism, instead of being a solution for creditors who are experiencing financial distress or bankruptcy. This phenomenon is different from some countries, such as in the

Rico Lesmana, Pedoman Menilai Kinerja Untuk Perusahaan Tbk, Yayasan, BUMN, BUMD, dan Organisasi Lainnya, (Jakarta: Elex Media Komputindo, 2003), hlm. 174. 
United States, the United Kingdom, and Hong Kong, which emphasize that bankruptcy is a mechanism for resolving debtors who have insolvency problems. Therefore, in these countries, a solvency test is required prior to a bankruptcy check. In Indonesia, however, such a test is not required for a debtor to be declared bankrupt. In Indonesia, the debtor's actions of not making a payment, either due to incompetence or unwillingness, are not taken into consideration.

This situation is similar to the bankruptcy regulations that apply in the Netherlands. Peter JM Declercq has emphasized that bankruptcy in the Netherlands focuses more on the debtors who do not pay their debts to creditors. The state is not interested in whether the debtor is incapable of making the payment or whether he simply chooses not to despite being capable of fulfilling his financial obligations. Declercq has stated, "A bankruptcy petition has to state the facts and circumstances that constitute prima facie evidence that the debtor has based to pay its debts. This is the case when there are at least two creditors, one of who has a claim that is due and payable and which the debtor cannot pay, refuses to pay, or simply does not pay".2

The absence of bankruptcy conditions for a state of insolvency is apparent in the provisions applied regarding the act of bankruptcy, as stipulated in Article 2 paragraph (1) in conjunction with Article 8 paragraph (4) of Bankruptcy Law. The provision only requires that the debt be not paid in full, collectible, and that at least two creditors be present. Moreover, the bankruptcy proving system is an additional requirement. Article 2 paragraph (1) in conjunction with Article 8 paragraph (4) of Bankruptcy Law does not require the presence of the debtor's insolvency.

\section{The utilization of Unwritten Law by the Judges in the Act of Bankruptcy}

The Bankruptcy Law states that an act of bankruptcy is determined by three conditions. The first condition is that the debtor has one matured debt that has not been paid in full and is collectible. Second, the debtor must have at least two creditors. Lastly, these two material requirements must pass a summarily proving (prima facie evidence).

These three requirements for the act of bankruptcy are stated as expressis verbis in Article 2 paragraph (1) in conjunction with Article 8 paragraph (4) of The Bankruptcy Law, which reads: "a debtor who has two or more creditors and does not pay in full, at least one matured and collectible debt, is declared bankrupt by the Court's decision, either on the petition itself or at the request of one or more creditors". Meanwhile, Article 8 paragraph (4) of The Bankruptcy Law states that, "the act of bankruptcy must be granted if there are facts or circumstances which provides summarily proving that the requirements for bankrupt declaration as referred to in Article 2 paragraph (1) are met".

There are both advantages and weaknesses of these three requirements. The advantages include providing a definite, fair and fast solution for bankruptcy settlement. By utilizing only three requirements, determining an act of bankruptcy is easy, summarily and fast. As a result of these benefits, the debtor may

Peter J.M. Declercq, Netherlands Insolvency Law, The Netherlands Bankruptcy Act and The Most Important Legal Concept (The Haque : T.M.C. Asser Press, 2002), hlm. 63. 
experience financial distress and wish to resolve the problem accordingly.

On the other hand, there are also weaknesses to this summarily solution, especially for solvent debtors with good faith, who can be considered bankrupt as long as they meet these requirements. The first condition to prove a bankruptcy is the presence of debtor's loan that is not paid in full, has fallen due, and is collectible. According to Bankruptcy law, a loan is an obligation expressed as an amount of money, both in Indonesian and foreign currencies, which arises due to an pre-ordained agreement, and which must be fulfilled by the debtor; If not fulfilled, it will provide the creditor the right to obtain the loan fulfilment from the debtor's assets.

The 2004 Bankruptcy Law defines debt in a more comprehensive manner than previous Bankruptcy Law. In the previous Bankruptcy Law, i.e. Law Number 4 of 1998 in conjunction with the Bankruptcy Regulation, the debt limit was not properly delineated, resulting in two interpretations from both academics and practitioners when the revised 1998 Bankruptcy Law came into force. One group, which interpreted debt in a narrower sense, stated that the term debt refers to debt arising from loan agreements in the form of a sum of money, and does not include performance that arises from the agreement beyond the loan agreement itself. Meanwhile, another group argued that the debt referred to in Article 1 of the Law includes performance that must be paid as a result of the engagement. Thus, this group interpreted debt in a broader sense.

The term debt here refers to civil liability law. Liabilities or debt can arise either from the contract or from the law (Article 1233 of Civil Code). This performance consists of giving something, doing something, or not doing something. Some judges in bankruptcy court also share this opinion.

In fact, in the Civil Code and the regime of civil law, debt is not acknowledged, either in the strict sense or a broader sense. Debt is simply debt, as stated in Article 1233 of the Civil Code. However, the terminology's discourse has developed in practice and in the expert's discourse. Of the two opinions regarding debt, the right opinion comes from the group that describes debt in a broad sense because the Bankruptcy Law is a more specific translation of the Civil Code. Therefore, debt, under the Law, is a performance, as stipulated in the Civil Code. In addition, related to the principle of debt pooling, bankruptcy is a means of distributing assets to creditors, not only in relation to the money-debt agreement but also in an engagement context.

Debt, in connection with the engagement, can arise because of an agreement and the law. Debt can arise from the law exclusively, and also as a result of a person's actions. The engagement born from the law, as a result of a person's actions, can be an action in compliance with the law or, on the other hand, a violation of the law (onrechtmatige daad).

In addition to adhering to the debt concept in the broadest sense, the concept used in regard to bankruptcy must fulfil the following requirements:

1. the debt has matured;

2. the debt is collectible, and

3. the debt is not paid in full.

A debt has matured when it reaches the agreed upon period of time; However, the debt can be billed even if it has not yet matured using the "acceleration clause" or "acceleration provision" and default clause. Setiawan has distinguished the acceleration clause from 
the default clause as follows: The acceleration clause gives the creditor the right to accelerate the debt's maturity period, if he/she feels insecure, whereas the acceleration clause is wider than the default clause and is employed when the creditor views necessary points even though the debt has not reached the due date. ${ }^{3}$ Creditors can accelerate the debt maturity in the event of a default, i.e., when the promises outlined by the debtor in the credit agreement are not fulfilled. Moreover, Setiawan has noted that use of the acceleration clause must be accompanied by good faith. This means that good faith constitutes reasonable evidence other than a court decision. ${ }^{4}$

Debt is considered collectible if it does not arise from natural engagement (natuurlijke verbintenis). An engagement whose fulfilment cannot be prosecuted is usually referred to as a natural engagement (natuurlijke verbintenis), and this cannot be used as an excuse to file an act of bankruptcy. Fred BG Tumbuan has stated that a natural engagement is an engagement whose fulfilment cannot be prosecuted under the legislation provisions of either (i) ab initio (from the beginning), such as in the debt that occurs because of gambling or betting (Article 1788 of the Civil Code), or (ii) as a result of expiration (Article 1967 of the Civil Code). ${ }^{5}$

Meanwhile, asserting that debt has not been paid in full is important to ensure that such debt can be used as a basis for filing an act of bankruptcy. This affirmation is necessary, because debtors will often make the minimum payment. It also comes from the experience of implementing an old bankruptcy regulation, namely Faillessement Verordening (Regulation of Bakruptcy) (FV), which requires that the debtor must have entirely stopped paying their debt; If the debtor is still paying it back, even if only in small amounts, the debtor cannot be considered as having stopped paying.

The second requirement is that the debtor have at least two creditors. Creditors are people who have receivables, based on an agreement, and can be billed before the court. Creditors are born not only because there is loan agreement, but also from all agreements and even because of the law. For instance, someone who purchases a new house from a property developer who has not yet received the transfer of the new house is considered a creditor. Thus, a creditor is born out of the property sales agreement. A tax office that has not received tax payments from a bankrupt debtor is also a creditor, due to taxation legislation.

Ratio legis, or the logical legal elements of bankruptcy conditions, are determined when there are at least two creditors because, theoretically, a bankruptcy is initially intended to divide insufficient assets to pay debts to creditors. If not confiscated as a result of bankruptcy, the insufficient debtor's assets will be overtaken by creditors in an unorganized manner, and their distribution will not be in accordance with the legal principles and legal norms of the business. However, the situation is different a debtor's asset are confiscated as

Setiawan Setiawan, "Pengertian Jatuh Tempo", dalam : Emmy Yuhassarie, Undang-Undang Kepailitan dan Perkembangannya (Jakarta: Pusat Pengkajian Hukum, 2004), hlm. 124.

Ibid.

5 Fred BG Tumbuan."Mencermati Makna Debitor, Kreditor dan Utang Berkaitan dengan Kepailitan", Dalam : Yuhassarie, Emmy.(ed.), Undang-Undang Kepailitan dan Perkembangannya (Jakarta : Pusat Pengkajian Hukum, 2004), hlm. 20-21. 
a result of bankruptcy: The creditors will not compete to receive payment, because the debtor's assets are in public status. Therefore, the collection of accounts receivable from the debtor cannot be directly made, but must go through the curator with a bankruptcy mechanism.

In bankruptcy, creditors are classified into three types, namely:

1. separatist creditor;

2. preferred creditor; and

3. concurrent creditor.

The division of creditors into the three classifications above is different from the distribution of creditors within the general civil law regime. In general, in civil law, creditors are either preferred creditor or concurrent creditor. In civil law, preferred creditors include creditors who have material security rights and those whose payments must be prioritized according to the law. However, in bankruptcy, preferred creditors are those who, according to the law, must pay the payment of their receivables, such as privilege holders, rights holders, etc. Meanwhile, creditors who have material guarantees, in bankruptcy law, are considered separatist creditors.

The existence of these three creditors is recognized. According to Dutch Bankruptcy Law, separatist creditors and preferential creditors have the right to apply for an act of bankruptcy (HR June 18, 1982, NJ/Netherlands Jurisprudence 1983,1$)$. This is supported by Abdul Hakim Garuda Nusantara, who cited Polak's opinion that creditors do not lose their authority to submit an act of bankruptcy for a debtor who stops paying.

The additional requirement to file an act of bankruptcy is a summarily proving, as specified in Article 8 paragraph (6) of The Bankruptcy Law. Article 8 paragraph (4) of The Bankruptcy Law declares that The petition for declaration of bankruptcy shall be granted if there are facts or circumstances summarily proving that the conditions for a declaration of bankruptcy as referred to in Article 2 paragraph (1) have been met. Further explanation on Article 8 paragraph (4) of Bankruptcy Law states that "Fact or condition that requires simple substantiation" shall mean the fact that there are two or more Creditors and there is indebtedness that has become due and payable but remain outstanding. The differences in the value of the indebtedness as argued by the bankruptcy petitioner and bankruptcy petitionee shall not prevent the issuance of bankruptcy declaration decision".

The norm outlined in Article 8 paragraph (4) of The Bankruptcy Law, along with the explanation provided in Article 8 paragraph (4), is rather vague and does not definitively state what is meant by summarily proving. Similarly, in general civil procedural law, the concept of summarily proving is not recognized, and thus its application raises several problems in court.

According to Kartini Mulyadi and Gunawan Widjaja, what is meant by summarily proving is the summarily proving of:

1. The existence of a debtor's debt requested for bankruptcy, which has matured;

2. The existence of two or more creditors from debtors who request for bankruptcy. ${ }^{6}$

A different opinion was provided by the Supreme Court in the National Working Meeting

6 Kartini Mulyadi and Gunawan Widjaja, Pedoman Menangani Perkara Kepailitan (Jakarta: Raja Grafindo Persada, 2004), hlm. 141. 
(Rakernas) held in September 2002, which attempted to limit the summarily proving, specifically to examine bankruptcy cases that do not recognize exceptions, replications, duplicates, conclusions or party claims. Therefore, the proving in a bankruptcy case is unilateral and not partial. The obligation to summon, as outlined in Article 8 paragraph (1) of The Bankruptcy Law, does not mean "calling" the debtor to submit answers, duplicates and conclusions. The summons of the debtor by a panel of judges during trial is intended to allow the debtor to hear the argument presented by the applicant (creditor). Therefore, examining the exceptions, answers, duplicates and conclusions in the General Court does not apply in a bankruptcy process. The Supreme Court provides an interpretation of summarily proving in regard to procedural law, while The Bankruptcy Law tends to process the proving itself.

It is important to verify the fact that two or more creditors exist and that the debt has fallen and has not been paid. The content of this article is closely related to the requirements that must be met to declare bankruptcy, as stipulated in Article 2 paragraph (1) of The Bankruptcy Law.

Upon review, the requirements of an act of bankruptcy are not difficult to prove, which is worrisome as the debtor loses their right to control and manage all of their wealth. Thus, bankruptcy is considered a 'death sentence' to asset management and ownership.

The terms of The Bankruptcy Law are relatively easily to fulfil, which raises an interesting legal issue regarding whether any act of bankruptcy that meets the requirements for bankruptcy, namely the presence of one unpaid debt, two creditors, and a summarily proving, should be granted by a judge in a court of law. Indeed, it is unclear whether a judge can reject an act of bankruptcy even it fulfils all three requirements, regardless of extenuating circumstances.

The authority of a judge to consider other factors beyond the predetermined bankruptcy requirements under Bankruptcy Law is determined in general and exceptional. In general, a judge must declare an act of bankruptcy if two conditions are met and can be verified. This is stipulated in Article 8 paragraph (4) of The Bankruptcy Law, which reads, "The petition for declaration of bankruptcy shall be granted if there are facts or circumstances summarily proving that the conditions for a declaration of bankruptcy as referred to in Article 2 paragraph (1) have been met". However, Bankruptcy Law regulates exceptions by providing discretionary space for judges to consider unwritten laws when making such decisions. This is stated in Article 8 paragraph (6) letter a of the Bankruptcy Law, which reads, "The Court's decision as referred to in paragraph (5) must also contain: a. a certain article of the legal regulation concerned and/or unwritten law sources which are used as a basis for judging".

Through Article 8 paragraph (6) letter a, The Bankruptcy Law allows judges to consider unwritten laws when deciding on an act of bankruptcy. Indeed, Bankruptcy Law is vague regarding the unwritten laws that can be considered by a judge in such decisions. The written provisions related to the trial of an act of bankruptcy, among others, include the aspects of public interest, reasonableness, justice, decency, and morality.

Judges should consider public interest when deciding on an act of bankruptcy, even if the application meets all the requirements. This idea 
is reflected in the bankruptcy of PT. Dirgantara Indonesia (PT. DI). The Cassation Judge overturned the decision of the Commercial Court of the Central Jakarta District Court, which had declared the company's bankruptcy. The cassation judge who overturned the bankruptcy of PT. Dirgantara Indonesia did so because the company was a vital industrial object in that the location, building, installation, and/or industrial business was related to the livelihood of many people, the country's interests and/or a source of the country's strategic income.

Meanwhile, in the case of an act of bankruptcy for the PT. Citra Jimbaran Indah Hotel, the board of judges revoked Judicial Review Decision Number 24 PK/N/1999 regarding the company's bankruptcy by considering the company's interests as a debtor and those of the creditors in a balanced manner. Furthermore, the judges felt that the potential prospects of the debtor's business should be considered thoroughly. If the debtor still has the potential to pay off the debt, they should still be given the opportunity. In addition, the debtors operated a five-star hotel located in a tourist area in Bali. Moreover, during the economic and financial crisis, the area was relatively unaffected.

\section{The Utilization of Unwritten Law in Bankruptcy Management and Settlement}

The court's verdict of declaring a debtor bankrupt does not necessarily mean the end of a bankruptcy case. Rather, it is the beginning of the debtor's bankruptcy status, with all the entailing legal consequences. One of the legal consequences of bankruptcy is the transfer of the debtor's bankruptcy assets to the curators under the supervision of the supervisory judges, whom are appointed by the court.
The management and settlement of a debtor's assets after bankruptcy by the curator, under the supervision of a supervisory judge, is immediately valid once the bankruptcy decision is pronounced. This is true even if the debtor files for a cassation or judicial review. A zerohour principle is immediately applied upon the enactment of a bankruptcy determination, meaning that the bankruptcy decision takes effect from 00:00.

Bankruptcy Law states that the supervisory judges are authorized to oversee the management and settlement of the bankruptcy estate. Their authority in this matter is active in nature, and includes making a decision or pronouncement, leading meetings and acting as the chairman in creditor meetings.

The existence of supervisory judges is crucial and necessary to the management and settlement of the bankruptcy estate. This is due to the heavy duty and responsibility of the curator, especially if the bankrupt debtor is a limited liability company. In addition, the supervisory judges supervise the curator's duties. Therefore, both the curators and the supervisory judges are crucial to the management and settlement of the bankruptcy estate. These institutions are independent, but inseparable. The supervisory judges are not superordinate to the curators, and the curators are not the subordinates of the supervisory judge. Both have their respective duties, authorities and responsibilities.

The supervisory judges preside over the creditor meetings, approve the curators, and establish a certain situation based on The Bankruptcy Law. However, some of the supervisory judges' actions are not specified in The Bankruptcy Law. Thus, their actions are often based on unwritten laws in consideration of justice, fairness, and propriety. It is common 
for stakeholders to sue supervisory judges based on their actions. The lawsuit against the actions of the supervising judges is tried by an administrative judge, who issues the bankruptcy pronouncement in a commercial court.

The actions of supervising judges who issue an insolvency status are based on unwritten laws, as in litigation case number 02/G.lainlain/2016/PN.Niaga.Sby. In this case, the supervisory judges issued a pronouncement regarding the insolvency status of the bankrupt debtor. The decision regarding the management and settlement of the bankruptcy estate was determined by Article 178 paragraph (1) of The Bankruptcy Law, which reads, "If at a meeting of verification claim, no reconciliation proposal plan is offered, the reconciliation proposal plan is rejected or the ratification of the reconciliation proposal plan is denied on the basis of court decision that has become final and conclusive, the be shall by law be in insolvency". In Article 178 paragraph (1), it is not clear whether the supervisory judge must issue a decision regarding the state of insolvency of the bankrupt debtor or when the date of the insolvency must be determined.

In case number 02/G.lain-lain/2016/ PN.Niaga.Sby, the judge issued an insolvency determination that was issued one month after no reconciliation was reached on the proving meeting. The judge's action was based on the compliance regarding the determination of insolvency and the issuance time of insolvency. The decision issued by the supervisory judge was sued to the administrative judge, who justified the steps taken by the supervisory judge. In his consideration, the administrative judge stated that, because the insolvency nature was due to the law (although there had been an insolvency pronouncement issued by the supervisory judge that turned out to be late from the date of the receivables-matching meeting) it cannot undo the determination of insolvency by the supervisory judge. This is considering that the date of the insolvency pronouncement does not affect the position of the bankrupt debtors (i.e., those who owe and have an obligation to pay the debt). Indeed, there is no law stating that the insolvency date, if it exceeds the date of the receviables-matching meeting, is null and void.

In this case, the supervisor judges issued an insolvency pronouncement against the debtor, even though The Bankruptcy Law does not regulate this point regarding the supervisory judge's authority to issue an insolvency pronouncement. The supervisory judge issued an insolvency pronouncement based on their discretionary authority within the framework of bankruptcy. Subsequently, the curator can begin to settle the bankruptcy estate, including conducting a bankruptcy auction after the debtor's bankruptcy status is in the insolvency stage. Similarly, in determining insolvency, regardless of the time that has lapsed without reconciliation being achieved, the supervisory judges are not restricted by The Bankruptcy Law. Therefore, these aspects are determined at the discretionary authority of the supervisory judges and based on considerations such as propriety, fairness and justice.

Next, the management and settlement of a bankruptcy estate is the duty and authority of the curator. The curator is an institution held by law to settle bankrupt estates. Vollmar has stated that, "De kurator is belast, aldus de wet, met het beheer en de vereffening van de failliete boedel". ' In each bankrupt pronouncement by the court, a curator is appointed to administer

Vollmar, De Faillessementswet (Haarlem: Tjeenk Willink \& Zoon N.V. 1998), hlm. 157. 
and transfer the bankrupt estate under the supervision of the supervisory judge.

As soon as the debtor is declared bankrupt by the court, the bankrupt is not legally authorized to administer and/or transfer the assets which have become bankrupt estate. It is the curator who does all legal actions, both in managing and transferring the bankrupt estate, under the supervision of the supervisory judge. From this proposition, it appears that the curator greatly determines the completion of the bankruptcy estate. Hence, the Bankruptcy Law explains the curator's authority and tasks to do.

The curator must not have any conflicts of interest. Moreover, the curator must not take sides with either the creditors or the bankrupt debtors. Rather, the curator must always be in favour of the law. In practice, the curator's name is submitted by the creditor who submits an act of bankruptcy to the debtor. However, even though the curator is suggested by the creditor, the curator must remain independent of bias.

The curator's responsibility is outlined in Article 72 of The Bankruptcy Law, which states that the curator is responsible for errors or omissions in performing management duties and/or negligence that causes losses to the bankrupt estate. Regarding the provisions of the curator's responsibility in The Bankruptcy Law, Jerry Hoff has argued the following: ${ }^{8}$ "In my opinion, this article does not create a static liability than would arise under the applicable rules for tort (Article 1365 of Civil Code). A receiver may be held liable if he has committed a tort. Any degree of fault is sufficient to create liability. The acts of the receiver will be compared with the acts a reasonably competent receiver. It may be argued, however, that the liability of a receiver must be judged by a higher standard if it has more than leverage expertise or experience."

Although The Bankruptcy Law outlines the duties and powers of the curator, these are left up to interpretation. Any matter not regulated by The Bankruptcy Law is addressed at the curator's discretion. Thus, the curator acts according to unwritten laws, such as common habits in the management and settlement of a bankruptcy estate, decency, rationality, and justice. The curator's decision is thus based on unwritten laws. The curator's authority to either continue or terminate a reciprocal agreement is regulated in Article 36 of The Bankruptcy Law. However, it is entirely at the discretion of the curator to determine, in what conditions, such a reciprocal agreement is continued or terminated.

A curator's decision to continue or terminate reciprocal agreements that have not been or only partially been fulfilled can be seen in the bankruptcy case of the condotel developers. The buyers of the condotel had made a Sales and Purchase Agreement (PPJB) with the developer. However, the condotel developer had fallen into bankruptcy before the Notarial Sales Agreement (AJB). This raised a legal issue regarding whether the PPJB could proceed with property title transfer of the condotel certificate or simply be discontinued. In such a case, the curator determines whether the PPJB can proceed to the Notarial Sales Agreement with a property title transfer, or simply be terminated. The curator can base his/her actions on unwritten laws and examine the case in isolation. 
In the bankruptcy case of PT. DAB (verdict number 06/Plw/pailit/2015/PN.Niaga Sby. In conjunction with verdict number 20/ pailit/2015/PN.Niaga.Sby.), the curator did not continue the Sales Agreement (AJB). Some of the condotel buyers filed other claims with the Commercial Court in the Surabaya District Court, so that the curator would proceed from the Sales Agreement to a Notarial Sales Agreement. The judge granted the lawsuit of the condotel buyers, and thus the curator proceeded with the Transaction Agreement. The judge decided that the condotel buyers would have paid in full in 2008. Since then, the legal relationship between PT. DAB and the three dispute objects ended and was transferred to the buyers; PT. DAB received the payment of the dispute objects in full. However, it did not take care of the Transaction Agreement documents and the issuance of the land/property deeds, nor were all documents related to the three dispute objects handed over. When declared bankrupt, the three objects were considered to be bankrupt estates. Legally, however, the disputed object had no legal relationship with PT. DAB, because the three dispute objects were still considered the property of the buyers. Thus, the administrative errors made by PT. DAB were not transferred to the buyers.

In this case, the administrative judge stated that the curator must proceed from the Sales Agreement to the Notarial Sales Agreement because it was based on decency and justice. The condotel buyers were paid in full and the properties were physically transferred. Therefore, it was appropriate for the curator to proceed to the Notary Sales Agreement. The fact that a Notary Sales Agreement was not made was not the condotel buyers' fault. Instead, it was the fault of PT. DAB, which had not realized its duty for various reasons. Therefore, it was unfair that the risks be imposed on the condotel buyers. In The Bankruptcy Law, there are no qualifications under which a reciprocal agreement is proceeded or terminated. This decision is at the discretion of the curator, and can be based on unwritten legal principles.

\section{Closing}

Bankruptcy law in Indonesia has several unique characteristics, namely, easy conditions for bankruptcy, does not require an insolvency test, and bankruptcy law serves a tool to collect debt. Unwritten laws are acknowledged in The Bankruptcy Law, especially in regard to the act of bankruptcy and the management and settlement of a bankruptcy estate. They are limited in nature, however, and are applied on a case-by-case basis.

The existence of unwritten laws is asserted by Article 8 paragraph (6) letter a of The Bankruptcy Law, which states that a judge can take unwritten laws into his/her consideration when deciding on a bankruptcy case. Similarly, in regard to the management and settlement of a bankruptcy estate, supervisory judges and curators are also given the discretionary authority to perform certain actions. The discretion of the supervisory judges and curators is based not on the norms of written The Bankruptcy Law but on unwritten principles, such as justice, propriety, fairness, etc.

Preferably for revisions to future bankruptcy so that the provisions regarding the use of unwritten law are further emphasized in bankruptcy both in bankruptcy applications and in the management of bankrupt assets. 


\section{Daftar Pustaka}

\section{Buku}

Declercq, Peter J.M., Netherlands Insolvency Law, The Netherlands Bankruptcy Act and The Most Important Legal Concept (The Haque : T.M.C. Asser Press, 2002).

Hoff, Jerry, Indonesia Bankruptcy Law (Jakarta : Tatanusa, 1999).

Lesmana, Rico, Pedoman Menilai Kinerja Untuk Perusahaan Tbk, Yayasan, BUMN, BUMD, dan Organisasi Lainnya (Jakarta: Elex Media Komputindo, 2003).

Mulyadi, Kartini dan Gunawan Widjaja, Pedoman Menangani Perkara Kepailitan (Jakarta : Raja Grafindo Persada, 2004).

Setiawan, "Pengertian Jatuh Tempo", Dalam : Emmy Yuhassarie, Undang-Undang Kepailitan dan Perkembangannya (Jakarta : Pusat Pengkajian Hukum, 2004).

Tumbuan, Fred BG, "Mencermati Makna Debitor, Kreditor dan Utang Berkaitan Dengan Kepailitan", Dalam : Yuhassarie, Emmy.(ed.), UndangUndang Kepailitan dan Perkembangannya (Jakarta : Pusat Pengkajian Hukum, 2004).

Vollmar. De Faillessementswet (Haarlem : Tjeenk Willink \& Zoon N.V. 1998).

\section{Peraturan Perundang-Undangan}

Indonesia. Undang-Undang tentang Kepailitan dan Penundaan Kewajiban Pembayaran Utang (Law on Bankruptcy and Suspension Of Obligation For Payment Of Debts). UU No. 37 Tahun 2004, LN No. 131 Tahun 2004. (Law No. 37 of 2004, SG No. 131 of 2004).

\section{Putusan Pengadilan}

Supreme Court of Republic of Indonesia "Decision No. 24 PK/N/1999".

Supreme Court of Republic of Indonesia "Decision No. 075/Pdt.Sus/2007".

Commercial Court of District Court of Central Jakarta, "Decision No. 48/PAILIT/2012/PN.NIAGA. JKT. PST".

Supreme Court of Republic of Indonesia "Decision No. 704 K/Pdt.Sus/2012".

Commercial Court of District Court of Central Jakarta, "Decision No. 09/Pdt.Sus/Pailit/2013/ PN.NIAGA.JKT.PST".

Commercial Court of District Court of Surabaya , "Decision No. 06/P/w/Pailit/2015/PN.Niaga Sby".

Commercial Court of District Court of Surabaya , "Decision No. 20/Pailit/2015/PN.Niaga.Sby".

Commercial Court of District Court of Surabaya , "Decision No. 02/G.Lain-lain/2016/PN.Niaga. Sby".

Commercial Court of District Court of Semarang , "Decision No. 13/Pdt.Sus-Pailit/2018/PN Niaga Smg jo 7/Pdt.Sus-PKPU/2016/PN Smg".

Commercial Court of District Court of Central Jakarta, "Decision No. 68/Pdt.SusMPKPU/2018/ PN.Niaga.Jkt.Pst". 